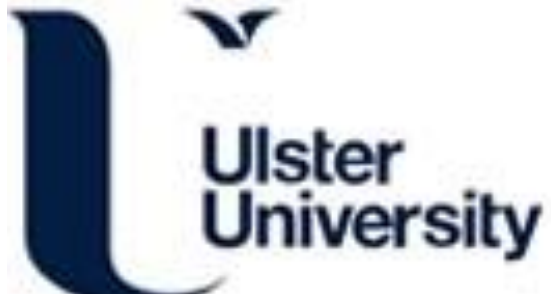

\section{Coastal defences versus coastal ecosystems: A regional appraisal}

Cooper, A., O'Connor, M., \& Mclvor, S. (2016). Coastal defences versus coastal ecosystems: A regional appraisal. Marine Policy, tbc. https://doi.org/10.1016/j.marpol.2016.02.021

Link to publication record in Ulster University Research Portal

\section{Published in: \\ Marine Policy}

Publication Status:

Published online: 02/03/2016

DOI:

10.1016/j.marpol.2016.02.021

\section{Document Version}

Author Accepted version

\section{General rights}

Copyright for the publications made accessible via Ulster University's Research Portal is retained by the author(s) and / or other copyright owners and it is a condition of accessing these publications that users recognise and abide by the legal requirements associated with these rights.

\section{Take down policy}

The Research Portal is Ulster University's institutional repository that provides access to Ulster's research outputs. Every effort has been made to ensure that content in the Research Portal does not infringe any person's rights, or applicable UK laws. If you discover content in the Research Portal that you believe breaches copyright or violates any law, please contact pure-support@ulster.ac.uk. 
Coastal defences versus coastal ecosystems: a regional appraisal

3 Abstract

4

5 Societal concern (both real and imagined) over coastal erosion and flooding, often results

6 in construction of sea defences to protect property. Sea defences are, however, damaging

7 to the natural ecosystems that provide quantifiable ecosystem services to the human

8 population. Protection of property is, however, the most common driving force behind

9 construction of sea defences and the basis of any associated economic appraisals.

10 Protection of the coastal ecosystem (sedimentary, biological and chemical) while

11 commonly implied in strategic documents (e.g. Habitats Directive 92/43/EEC, Water

12 Framework Directive 2000/60/EC, OSPAR Convention), remain largely aspirational

13 notions that currently have a much lower priority, or none at all, in sea defence decision-

14 making. Under this anthropic view of coastal protection it is not surprising that defence

15 structures proliferate. In many instances, shoreline armouring is considered on a case by

16 case basis with little regard to the cumulative effects. This is true whether or not there is

17 a strategic approach to coastal protection. In this paper the Northern Ireland coast is used

18 as a case study to document the nature and extent of shoreline protection structures

19 associated with sandy beaches. The nature and extent of sea defence structures were

20 documented from a low-level oblique helicopter-based photographic survey and mapped

21 in a GIS. The implications for the coastal ecosystem are considered. A sustainable

22 approach to shoreline management demands a balance between protection of property

23 and preservation of coastal ecosystem services. 


\section{Introduction}

27 Coastal erosion and flooding is often cited as posing a risk to built infrastructure. This is

28 a legitimate societal concern which does of course highlight that the infrastructure is

29 located in a hazardous location. For many types of infrastructure (harbours, power

30 plants, ports etc.) this is unavoidable and is either tacitly accepted as an operational risk,

31 and/or minimised by construction of defences. Many other examples of infrastructure,

32 however, do not need to be built in coastal locations and the root of their problems with

33 coastal flooding and erosion lie in poor contemporary land-use planning or are inherited

34 from periods when the risks were less understood. In some such cases where levels of

35 risk are very low and only extreme events with low recurrence intervals pose a threat,

36 communities have learned to accept the risk: the costs of preventing a low frequency risk

37 are prohibitive and thus it is regarded as acceptable to live with it. In others, defences of

38 various sorts are constructed to protect property.

40 The perceived or real threat to infrastructure is, however, often the dominant or only

41 concern considered in the societal response to flooding or erosion (Penning-Rowsell et

42 al., 2012). Typical of contemporary societal views is the statement by Marchand et al.

43 (2011, p859) that "Coastal erosion in Europe causes significant economic loss, ecological

44 damage and societal problems", without making either of the equally valid but opposing

45 statements that (i) coastal erosion provides many societal benefits through its contribution 
46 to coastal ecosystem services (in particular sustaining beaches) and (ii) efforts to combat

47 coastal erosion are damaging to coastal ecosystems and the services they provide.

49 Constructing coastal defences (whether hard or soft) to protect human infrastructure has

50 deleterious effects on the coastal ecosystem (including reducing or eliminating sediment

51 supply, preventing energy attenuation, reflecting or redirecting excess energy, reducing

52 or eliminating habitat (coastal squeeze), and altering habitat type (Greene, 2002; Jones et

53 al., 2011). In a review of the losses of coastal and nearshore marine habitats in Europe,

54 Airoldi and Beck (2007, p345) note that "coastal development and defence have the

55 greatest impact on soft-sediment habitats...". These in turn negatively impact important

56 coastal ecosystem services such as recreational area, landscape/seascape quality, storm

57 attenuation, food production, assimilation of pollutants amongst other things (UK

58 National Ecosystem Assessment, 2011). These effects are often ignored or overlooked in

59 deference to the perceived social desirability of protecting infrastructure rather than

60 ecosystems (Cooper and McKenna, 2008).

61

62 In large part, concern about coastal erosion and flooding is only loosely focussed and 63 terms such as 'coastal protection' and 'working with natural processes' mean different

64 things to different people (Cooper \& McKenna, 2008). Protecting a beach is not the 65 same as protecting a house behind the beach- to protect the house means damaging or 66 destroying the beach, while protecting the beach may mean letting the house collapse 67 when erosion reaches it, yet both meanings are encompassed in the term 'coastal 68 protection'. Importantly, the different interpretations of these terms are diametrically 
69 opposed- following one interpretation will compromise the other. The concept of

70 'building with nature" that is popular in the Netherlands at present (Van Koningsveld et

71 al., 2008) is another example. In order to resist any movement of the shoreline from its

721991 position (whether by storms or sea level rise), beach nourishment is an essential part

73 of the strategy. Concepts such as the 'sand engine', a massive beach nourishment scheme

74 that is anticipated by its designers to spread sand along the coast over several years, are

75 billed as examples of building with nature. Such efforts may rely on natural processes to

76 redistribute sand, but the underlying cause for installation is to resist nature.

77 Consequently the very term is disingenuous.

79 In practice, protection of property is the most widespread context within which the term

80 'coastal protection' is invoked. Protection of the coastal ecosystem (sedimentary, 81 biological and chemical) while implied in policy documents (EU, OSPAR), has a much

82 lower priority. This probably stems from the perceived immediacy of flooding or erosion

83 risk versus the long-term benefits and cost associated with coastal ecosystem services.

84 Under such an anthropic view of coastal protection it is not surprising that defences

85 proliferate. Recent reviews of the state of Europe's coasts (EEA, 2006; 2011) show a

86 progressive increase in the extent of coastal defences. While this is a response to ongoing

87 development on the shoreline (Airoldi and Beck, 2007), it has implications for

88 sustainability of the coast which have received little attention. In Europe the Water

89 Framework Directive might in due course focus attention on the extent to which coastal

90 and estuarine ecosystems have been compromised by sea defences, but in the meantime, 
91 progressive shoreline armouring poses a major threat to the natural functioning of the

92 coastal marine ecosystem.

93

94 In many (almost all) instances, shoreline armouring is considered on a case by case basis

95 with little regard to the cumulative effects. This is true whether or not there is a strategic

96 approach to coastal protection. In this paper we use the Northern Ireland coast as a case

97 study to document the nature and extent of shoreline armouring in place, and consider the

98 implications for the coastal ecosystem. We assess the need for an integrated approach to

99 shoreline management that considers protection of the coastal ecosystem as well as

100 protection of coastal property in order to derive a sustainable approach to coastal

101 protection.

102

103 2. Study Area

104

105 The Northern Ireland coast (Figure 1) extends from Warrenpoint on Carlingford Lough,

106 to Londonderry on Lough Foyle (Cooper, 2010). The open coastline is approximately 650

$107 \mathrm{~km}$ in length of which more than $75 \%$ is under some form of statutory or non-statutory

108 conservation designation. An additional $113 \mathrm{~km}$ of coast is contained within the sea

109 loughs (semi-enclosed marine embayments) of Carlingford, Strangford, Larne and Foyle.

110 Nature conservation designations applied to sections of the coast include the World

111 Heritage Site of The Giants Causeway and Special Areas of Conservation such as

112 Strangford Lough and the Bann Estuary (Department of Environment, 2010). Over 70\%

113 of the coastline is classified as an 'Area of Outstanding Natural Beauty (AONB)' 
114 (McLaughlin \& Bann, 2002). There is, however, no strategic approach to shoreline

115 management in Northern Ireland (Dodds et al., 2010) and decision-making regarding

116 coastal defences is conducted by a variety of past and present government bodies

117 operating largely independently to fulfil their statutory obligations (Cooper, 2011). With

118 no strategic approach to shoreline management, a wide variety of structures has been

119 emplaced at various times.

120

121 (Figure 1.)

122

123 3. Methods

124

125 In 2009 a low-level helicopter aerial survey of the Northern Ireland coast was 126 commissioned by the Maritime and Coastguard Agency (MCA) and Northern Ireland

127 Environment Agency (NIEA) to identify access points for potential marine accidents.

128 This resulted in a complete photographic coverage of the coast by low level (100ft)

129 oblique aerial images whose origin was geo-referenced in a GIS. In this study these

130 images were used to identify the nature and extent of sea defence structures, whose

131 location was mapped in GIS using a 1:10,000-scale base map. In the GIS the location,

132 nature and extent of sea defence structures associated with sandy beaches was mapped.

133 The nature of what type of asset was protected was also assessed. Ground-truthing of

134 selected sections of the coast was undertaken via field visits to confirm the type of 135 defence structure identified from the aerial photography. 
139 There is a long history of sea-defence structures in Northern Ireland, many of which were 140 originally constructed to create safe harbours and facilitate navigation. In the $18^{\text {th }}$ and

141 particularly $19^{\text {th }}$ century land claim in estuaries involved construction of sea defences that

142 persist to the present time while in the $19^{\text {th }}$ and $20^{\text {th }}$ century construction and metaling of

143 coastal roads was accompanied by construction of sea defences. Several arterial roads

144 extend around the coast of Northern Ireland, including the Antrim Coast Road which was

145 considered a major feat of engineering at the time of its construction between 1832 and

1461842 (Orr, 2010). In the more recent past, a variety of embankments have been

147 constructed in seaside resort towns to provide promenade access. In the past two decades

148 in particular a variety of sea defences have been emplaced to protect individual seaside

149 dwellings as well as caravan sites, agricultural fields, car parks and municipal facilities.

150 Several seaside resorts (e.g. Portrush, Newcastle, Bangor, Millisle) have seen continuing

151 construction and alteration of existing sea defences in efforts to improve civic amenity.

153 A variety of shoreline protection works are present in Northern Ireland. Formal rock

154 armour involves large quarried stones placed along the shoreline in a systematic fashion.

155 The rock is usually hard igneous rock (basalt or granite). The rocks are selected to 156 withstand a specified wave impact and are emplaced to a particular design. They are not

157 cemented in place. Vertical sea walls constructed of blocks of rock cemented together are 158 also common. They tend to be historical features and many have recently been replaced 159 by concrete sea walls. 
161 Informal rubble is frequently used as an alternative to rock armour, whereby blocks of

162 material, such as old concrete or bricks in various shapes and sizes are placed on the

163 coast to dissipate some of the wave energy. This is usually done in an informal manner

164 without design and often the material is simply dumped. It is most common on

165 agricultural fields and private property (caravan parks and houses).

167 A variety of concrete seawalls have been constructed in Northern Ireland to protect the

168 landward assets from erosion. They range from vertical walls that simply reflect wave

169 energy to concave curved walls designed to re-direct incident wave energy. Several are

170 topped by promenades or roads. Railway sleepers were used as a seawall at Cushendun.

172 Groynes, timber or concrete walls built perpendicular to the shoreline, designed to trap 173 sand moving alongshore, have been constructed at a few locations in Northern Ireland.

174 They are not common because most beaches are located in headland-bounded 175 embayments in which longshore drift is subordinate to cross-shore transport (Cooper, 176 2013). Examples are present at Portballintrae (Jackson, 2012), Newcastle and Ballyholme

178 Flood embankments are designed primarily to prevent flooding of low-lying areas rather 179 than prevent erosion. They are present in some of the sea loughs, particularly in front of 180 reclaimed salt marsh and tidal flats in Strangford Lough and Lough Foyle. 
184 In total, $32 \%$ of the Northern Irish coast is fronted by man-made structures, with $68 \%$

185 natural. The extent of defended coastline compares to $44 \%$ in England and Wales, and 186 6\% in Scotland (Defra, 2010).

$188 \quad$ 5.1. $\quad$ North Coast

189 The sand beaches of the North Coast (Magilligan to Ballycastle) (Fig. 2) are among the

190 least developed in Northern Ireland. The high cliffs and lack of coastal roads that directly

191 impinge on beaches is the main reason. Nonetheless several do have sea defences

192 landward of the beach. These are most prominent at Portrush, the region's main seaside

193 resort. On the West Strand concave seawall and promenade are present along the rear of

194 the beach which has lowered significantly since the wall was built. On the neighbouring

195 East Strand, in contrast, a seawall and promenade suffers from regular inundation with

196 wind-blown sand. Both walls seem to have been emplaced to facilitate pedestrian access

197 on the associated promenade. Some rock armour and gabbions were emplaced at

198 Whiterocks beach, Portrush at the toe of a high dune in order to protect part of a golf

199 course (Fig. 3). The sea defence situation at Portballintrae was documented by Jackson

200 (2013), who catalogued a series of interventions that led first to destruction of the beach

201 and subsequently the need to armour the glacial bluffs.

202

203 (Fig.2 and Fig. 3)

204

$205 \quad$ 5.2. $\quad$ North Antrim Coast 
206 At Ballycastle the coastal orientation changes to run N-S (Fig. 4). Between Ballycastle

207 and Larne is a series of glaciated valleys (the Antrim Glens) with headland-embayment

208 beaches at the mouths of the valleys. The Antrim Coast Road runs semi-continuously

209 along the shoreline and a number of small settlements are present. At Cushendun

210 (Fig.5A,B), sand removal from the beach had caused beach erosion and shoreline retreat

211 (Carter, 1991). Rock armour and railway sleeper defences were built to protect adjacent

212 land. The practice of sand removal has now stopped and the walls are not being

213 maintained. At neighbouring Cushendall, a seawall and promenade was built in front of

214 a golf clubhouse. The wall collapsed during storms in 1996 and again in 2014. The

215 Antrim coast Road runs adjacent to the shoreline and where it impinges on the shore, sea

216 defences have been constructed at the rear of many beaches (Fig. 5E, F). In many cases

217 such beaches are now entirely covered at high tide and the sea defences are subject to

218 high wave energy.

219

$220 \quad$ (Fig.4 and Fig. 5)

221

222

223

\subsection{Outer Ards Coast}

225 A road runs semi-continuously along the outer coast of the Ards Peninsula connecting

226 several small towns and villages (Fig. 6). Beaches are present in embayments on this

227 low-lying rocky coast and where the road impinges on the beach, sea defences have been

228 built (Fig.7). The beach margin of several caravan sites (mainly occupied by 
229 holidaymakers in the summer season) are armoured with a variety of materials and most

230 of the holiday and permanent homes built seaward of the road are defended by rock

231 armour. The raised beach deposits along this stretch of coast were a source of sand

232 during storms and a future sand reservoir that would be accessed as sea level rises. This

233 has been rendered inaccessible to the beach by the sea defences. The popular seaside

234 resorts of Bangor, and Donaghadee have promenades at the rear of beaches. For

235 example, Ballyholme beach at Bangor is backed by a seawall topped by a promenade.

236 This has cut off the supply of sand from a formerly eroding bluff to landward.

237 Unsuccessful efforts to prevent the inevitable beach lowering involved construction of 238 groynes which are now in a poor state of repair.

$240 \quad$ (Fig. 6, 7, 8.)

\subsection{South Down Coast}

244 South of the Ards peninsula, the County Down coast is a mix of hard rock and soft glacial 245 deposits. The beaches are sustained by ongoing erosion of the soft glacial deposits 246 immediately landward of them.

248 Roads are present at variable distances landward of the shoreline (Fig. 9). Where it 249 impinges on the shoreline it has been defended. The largest single sea defences adjacent 250 to beaches are at the resort of Newcastle and around caravan sites at Cranfield Point. The 251 resort of Newcastle is fronted by a seawall (Fig. 10A) and a recreational centre was 
252 constructed on top of part of the beach. Erosion of the shoreline has progressed

253 alongshore from the initial hard defences in front of the town and adjacent areas

254 (including a hotel and golf course) have been armoured in turn. The seawall in front of

255 the largest hotel (Fig 10B) has collapsed during storms in 2002 and was rebuilt.

257 Outside these resorts sea defences at the rear of the beach have been constructed to 258 protect individual houses, footpaths (Fig.10C) and agricultural land (Fig 10D).

$260 \quad$ 5.5. $\quad$ Sea Loughs

262 Beaches and tidal flats are present within all of Northern Ireland's sea loughs. They are

263 large marine embayments in which wave energy is significantly lower than the open sea,

264 but within which periodic storms can cause significant morphological change. A variety 265 of sea defences are present at the rear of beaches in these sea Loughs (Fig.11). They 266 have been constructed for various reasons. In Strangford Lough the most common sea 267 defences are constructed to protect roads which run along the margins of the Lough. 268 (Fig11D). A single large structure at the landward limit of tidal flats in the north of the 269 lough was constructed originally as part of a saltmarsh reclamation project (McErlean et 270 al., 2002). It has subsequently been enhanced and strengthened several times to provide 271 flood and coastal defence for the low-lying parts of Newtownards. Other areas in 272 Strangford are defended to protect small patches of ground including picnic sites (Fig 273 11B). Approximately 25\% of Strangford Lough's mainland shoreline (excluding its 274 islands) is armoured. 
276 Over $40 \%$ of the Northern Ireland section of Carlingford Lough's coastline is defended

277 by sea defence structures. Most of these consist of rock armour and seawalls to protect

278 the A2 road. Several additional stretches of armouring have been emplaced to protect

279 individual houses (Fig 11E) or new developments (Fig 11F).

281 Almost $50 \%$ of the shoreline of Belfast Lough has defensive structures. Much of this is

282 protecting roads and other urban and port-related infrastructure. Some, however, is 283 present at the rear of small pocket beaches such as those at Crawfordsburn (Fig. 11A).

284 The purpose of these defences seems to be primarily to provide support for a footpath at 285 the rear of the beach.

287 Just less than $30 \%$ of Larne Lough's coastline comprises sea defences, constructed in 288 association with port facilities and to protect roads.

290 About $40 \%$ of Northern Ireland's Lough Foyle coastline comprises sea defences with 291 most of these constructed to protect reclaimed salt marshes.

\section{Effects of coastal defences on the coastal ecosystem.}

295 Erosion of shorelines and periodic flooding are entirely natural processes of coastal 296 ecosystems. Shoreline erosion may be a response to a temporary increase in wave or

297 tidal energy or a sediment imbalance that is either temporary or long-term. In the natural 
298 world erosion is a mechanism by which the coastline adjusts to changing conditions.

299 Erosion of land seaward of, or alongshore of beaches, provides a sediment source that

300 sustains some beaches and yields sediment to the nearshore zone. Flooding too is a

301 temporary condition during which excess water is accommodated within a system.

302 During floods, wetlands (e.g. saltmarshes) are supplied with fresh inputs of sediment and 303 nutrients.

304

305 Coastal defences compromise the natural sedimentary system and the associated coastal 306 ecosystem (McKenna et al., 2000). They do so in a number of ways and at different

307 timescales. In areas where the supply of sand or gravel to beaches is dependent on 308 periodic bluff erosion, sea defences eliminate or reduce the sediment supply. This effect 309 was noted by Carter (1984) in the case of the Antrim Coast Road where the road had 310 severed the supply of cliff-derived debris from the adjacent cobble beaches. Active cliff 311 recession also sustains beaches on the coast south of Newcastle and around Strangford 312 Lough. Ultimately any reduction in sediment supply causes such beaches to narrow and 313 ultimately disappear as the existing sediment is reworked by waves. On long stretches of 314 the Northern Ireland coast, a 'raised beach' deposited during a previous high sea level is

315 present behind the modern beach. It contains a large supply of sediment but much of it 316 has been rendered inaccessible to the modern sedimentary system by seawall 317 construction. This effect is particularly noticeable on the outer Ards Peninsula where the 318 coast road and small settlements have been built on the raised beach. In other areas, 319 erosion of glacial sediments is the only contemporary source of sediment to beaches and 320 tidal flats (Greenwood and Orford, 2007). 
322 Armouring at the rear of many sand beaches cuts the link between beach and dune, thus

323 preventing the additional dissipation of storm energy that occurs by dune erosion during

324 storms (McKenna et al., 2000). It also creates 'edge effects' where erosion is focussed as

325 the margins of the defences causing them to be gradually extended- the beach at

326 Newcastle County Down is a good example where Navas and Cooper (1998) showed the

327 progressive extension of sea defences. Separation of beach and dune by seawalls cuts the

328 sediment supply from dunes that is often part of the natural post-storm recovery

329 mechanism (Lynch et al., 2009). This means that excess energy remains within the

330 system and is used to export sediment seawards.

332 The direct effects of shoreline armouring include reflection of waves during storms. This

333 leads to enhanced offshore transport of sediment. Carter (1991) reported a 2m drop in

334 beach level at Portrush since construction of a sea wall. In other instances armouring has

335 caused loss of beach habitat by being constructed on top of the beach. A recreational

336 facility at Newcastle is a prime example that is extended onto the former beach and now 337 overlies it.

339 In the medium term anticipated changes in global sea level and its outworking at local

340 level as relative sea level rise have serious implications for coastal sedimentary systems

341 and ecosystems. Although Northern Ireland has historically seen little sea level rise (due

342 to post-glacial land uplift) recent studies point to a rising sea level trend (Orford et al.,

343 2006) Rising sea level typically causes a landward migration of shorelines as dynamic 
344 zones shift landwards and upwards. A migrating shoreline rising across the coastal

345 hinterland results in erosion of adjacent materials liberating sediment that, in turn, 346 sustains the migrating landforms. The glacial sediments and raised beaches of the

347 Northern Ireland coast contain a ready source of beach-building material that will be

348 accessed by the rising sea. In cases where this has been armoured the future sediment

349 supply has been cut off and beaches will be lost.

351 The same is true for tidal flats. In all the sea loughs, armouring at the landward margin of

352 the tidal flats inhibits the ability of the tidal flats to migrate and they will thus narrow and

353 become more energetic as wave energy is dissipated across a narrower zone. The

354 implications for resident and migratory creatures are potentially serious. In a study for

355 the National Trust Orford et al. (2006) contended that about 50\% of the intertidal habitat

356 at the northern end of Strangford Lough (backed by a sea defence) would be lost if sea

357 level were to rise by $1 \mathrm{~m}$ in the next century. Tidal flats not backed by seawalls could

358 instead migrate landwards.

360 Decreased width reduces the natural coastal defence capacity of beaches, tidal flats and

361 salt marshes. An inability to access sand dunes during storms has the same effect since

362 excess energy is then reflected seawards, causing enhanced erosion, rather than being 363 dissipated in the dunes.

365 There are many ecological implications of coastal armouring on sandy beaches and tidal 366 flats (Dugan et al., 2008; Defeo et al., 2009). Perhaps most fundamentally, a reduced 
367 area for beach debris (e.g. seaweed) to accumulate causes a marked reduction in beach

368 productivity. The reduced areas of beaches and tidal flats also provide less habitat area

369 for foraging and nesting birds and other beach-dependent organisms (Dugan and

370 Hubbard, 2006). The coastal defence structures themselves become habitats that impact

371 on native biological communities and can promote colonisation by invasive creatures

372 (Defeo et al., 2009). The loss in area of beaches, caused by sea defence structures

373 ultimately impacts on the entire nearshore ecosystem via a complex set of interacting

374 nutrient and material flows.

375

376 7. Discussion

378 Over a quarter of all Northern Ireland's sandy beaches are backed by sea defences. The 379 reasons for emplacement of coastal defences are varied, but the most common (defence 380 of roads and defence of homes) relate to structures that do not necessarily have to be built

381 on the coast. In many instances, even low value and undeveloped land is defended at 382 great expense. In a number of instances armouring of sand beaches appears to have been 383 an unnecessary 'knee-jerk' reaction to winter storms - several seawalls between the

384 beach and dune appear to serve no practical purpose. In the case of seaside resorts, 385 defences at the rear of beaches serve mainly as the basis of a promenade.

387 With few exceptions (one of which was the upgrade of Newtownards sea defences 388 (Navas et al., 2002)), construction of sea defences takes little account of the 389 environmental or ecological implications either individually or cumulatively for the 
390 Northern Ireland coast. Applying Kahn's (1966) premise regarding the "the tyranny of

391 small decisions" to environmental impacts Odum (1982) noted that the effects of small,

392 independent decisions are often experienced post hoc and they often result in detrimental

393 outcomes in which the larger issue is never directly addressed. This appears to be the

394 case regarding sea defences behind beaches in Northern Ireland and elsewhere. One

395 project might be administratively acceptable and have subtle effects on habitats and

396 organisms, but numerous projects over time may exert multiple assaults that result in

397 "death by a thousand cuts (Lindeman, 1997b)." With rising sea level and increasing

398 development, the demand for protection of built infrastructure and property will

399 undoubtedly increase. The impacts on the coastal ecosystem are likely to continue to be

400 ignored (Greene, 2002).

401

402 In addition, despite a brief phase of government engagement with ICZM (Cooper, 2011),

403 Boyer-Villemaire et al. (2014a,b) have drawn attention to the shortcomings in the

404 administration of coastal management and the lack of participation by citizens in

405 decision-making in coastal defence specifically in Northern Ireland. This, coupled with a

406 general lack of awareness of the impacts of coastal defences, is a major challenge to

407 changing the status quo.

408

409

$410 \quad$ 8. Conclusions

411 
412 The prevailing one-dimensional view of coastal protection in Northern Ireland, and

413 indeed globally, is causing severe impacts on natural coastal ecosystems and

414 compromising their ability to adapt and survive during rising global sea level. This

415 situation is the result of several combined factors. These are:

417 1. Ignorance on the part of the public and managers of the implications of sea 418 defences for coastal ecosystems;

419 2. Structuring of decision-making processes such that some form of defence is the $420 \quad$ only plausible outcome;

421 3. Active lobbying for engineered interventions by the engineering profession;

422 4. Poor planning decisions that permit construction in high risk zones;

423 5. A higher priority being afforded to private property than maintenance of the $424 \quad$ communal coastal resource; and

425 6. An inability to contemplate large scale removal of infrastructure to less vulnerable $426 \quad$ locations.

428 The inevitable outcome is an ever-increasing maintenance bill for sea defences and an 429 ever more degraded environment with implications for the quality of life of residents, 430 impacts on tourism and recreation (that rely to a large extent on a high quality scenic 431 environment) and deleterious impacts on the natural coastal ecosystem. Protection of 432 some types of infrastructure at the coast is of course needed, but in many cases more 433 sustainable alternatives to defence can be found. In many instances defence measures 434 were unnecessary and can safely be removed. Amenity can be provided by less intrusive 
435 and even demountable structures such as being implemented by the National Trust at

436 Portstewart beach. From a planning perspective, a strategic approach to the shoreline is

437 needed that makes it clear that ill-placed development will not be permitted to be

438 defended. This would have the immediate effect of still enabling development at the

439 owners risk but would halt the ongoing pattern of development in erosion-prone locations

440 with inevitable subsequent calls for armouring (even at public expense).

441

\section{Acknowledgements}

444 This work was undertaken in the context of the IMCORE (Innovative Management for

445 Europe's Changing Coastal Resource) Project funded under the Interreg IVB programme.

446 We are grateful to NIEA for access to its oblique aerial photography set from which 447 information on sea defences was mapped.

449 References

451 Airoldi, L. and Beck, M.W. 2007. Loss, status and trends for coastal marine

452 habitats of Europe. In: Gibson, R.N., Atkinson, R.J.A. and Gordon, J.D.M.

453 (eds). Oceanography and Marine Biology: Annual Review, 45, 345-405.

455 Boyer-Villemaire, U., Benavente, J. Cooper, J.A.G. and Bernatchez, P. 456 2014a. Analysis of power distribution and participation in sustainable 
457 natural hazard risk governance: a call for active participation. Environmental 458 Hazards, 13, 38-57.

460 Boyer-Villemaire, U., Bernatchez, P., Benavente, J., and Cooper, J.A.G. 461 2014b. Quantifying community's functional awareness of coastal changes 462 and hazards from citizen perception analysis in Canada, UK and Spain. 463 Ocean and Coastal Management. 93, 106-120.

464

465 Carter, R.W.G. 1991. Shifting Sands. A study of the Northern Ireland Coast 466 from Magilligan to Larne. HMSO, Belfast, 49pp.

468 Coastal Channel Observatory (2007) Breakwaters Available online: 469 http://www.channelcoast.org/southwest/programme_design/defence_type/?li 470 nk=breakwaters.html last accessed 26/01/11

472 Cooper, J.A.G. 2010. 7.25 Northern Ireland. In: Bird, E.C.F. (ed) 473 Encyclopedia of the World's Coastal Landforms, Springer-Verlag Berlin, $474 \quad 536-544$. 
476 Cooper, J.A.G. 2011. Progress in Integrated Coastal Zone Management

477 (ICZM) in Northern Ireland. Marine Policy, 35, 794-799.

478

479 Cooper, J.A.G. 2013. Ireland. In: Pranzini, E. and Williams, A.T. (eds)

480 Coastal Erosion and Protection in Europe. Earthscan, Routledge, 209-226.

481

482 Cooper, J.A.G. and McKenna, J. 2008. Working with natural processes: the 483 challenge for Coastal Protection Strategies. Geographical Journal 174, 315484331.

485

486 Department of Environment (2010) Coast and Sea Available online: 487 http://www.doeni.gov.uk/niea/biodiversity/habitats-2/coast.htm Last $488 \quad$ Accessed 26/01/11

490 Dodds, W., Cooper, J.A.G. and McKenna, J., 2010. Flood \& Coastal 491 Erosion Risk Management Policy Evolution in Northern Ireland: 492 “Incremental or Leapfrogging?" Ocean and Coastal Management, 53, 779493786. 
496 Defeo, O., McLachlan, A., Schoeman, D. S., Schlacher, T.A., Dugan, J.,

497 Jones, A., Lastra, M. and Scapini, F. 2009. Threats to sandy beach

498 ecosystems: A review. Estuarine, Coastal and Shelf Science, 81, 1-12.

500 Defra (Department for food, rural and agricultural affairs) (2010) Charting

501 Progress 2 available online: http://chartingprogress.defra.gov.uk/ministerial-

502 foreword Last accessed: 26/01/11

503

504 Dugan, J.E. and Hubbard, D.M. 2006. Ecological responses to coastal 505 armouring on exposed sandy beaches. Shore and Beach, 74, 10-16.

506

507 Greene, K. 2002. Beach Nourishment: A Review of the Biological and 508 Physical Impacts ASMFC Habitat Management Series \# 7. Atlantic States

509 Marine Fisheries Commission, Washington, D.C.

510

511 Greenwood R. O. and Orford J. D., 2007. Factors Controlling the Retreat of

512 Drumlin Coastal Cliffs in a Low Energy Marine Environment-Strangford

513 Lough, Northern Ireland. Journal of Coastal Research, 23, 285 - 297. 
515 Jackson, D.W.T. 2013. Portballintrae Bay, Noirthern Ireland: 116 years of

516 misplaced management. In: Cooper, J.A.G. and Pilkey, O.H. (eds). Pitfalls

517 of Shoreline Stabilization, Springer, New York. 93-105.

519 Jones, L., Angus, S., Cooper, A., Doody, P., Everard, M., Garbutt, A.,

520 Gilchrist, P., Hansom, J., Nicholls, R., Pye, K., Ravenscroft, N., Rees, S.,

521 Rhind, P., Whitehouse, A., 2011. Coastal margins. Chapter 11. UK

522 National Ecosystem Assessment. UNEP-WCMC, Cambridge.

524 Kahn, A.E. 1966. The tyranny of small decisions: market failures, 525 imperfections, and the limits of economics. Kyklos 19:23-47.

527 Lynch K, Jackson DWT, Cooper JAG. 2009. Foredune accretion under 528 offshore winds. Geomorphology, 105, 139-146.

530 Marchand, M., Sanchez-Arcilla, A., Ferreira, M., Gault, J., Jiménez, J.A., 531 Markovice, M., Mulder, J., van Rijn, L., Stănicăf,A., Suliszg, W. and 532 Sutherland, J. 2011. Concepts and science for coastal erosion management 533 An introduction to the Conscience framework. Ocean \& Coastal 534 Management, 54, 859-866. 
536 McErlean, T., McConkey, R. and Forsythe, W. 2002. Strangford Lough: An

537 Archaeological Survey of the Maritime Cultural Landscape. Blackstaff 538 Press, Belfast. $689 \mathrm{pp}$

540 McKenna J, MacLeod M J, Power J and Cooper J A G 2000. Rural beach 541 management: a good practice guide. Donegal County Council, Lifford. 542 Available at: http://uir.ulster.ac.uk/12436/1/GPG_Atlantic_Beaches.pdf

545 McKenna, J. Cooper, J.A.G. and O’Hagan, A.M. 2009.Coastal erosion 546 management and the European principles of ICZM: local versus strategic 547 perspectives. Journal of Coastal Conservation, 13, 165-173.

549 McLaughlin \& Bann (2002) Human use and management of the Northern

550 Ireland coast in Knight, J. (Ed.) Field Guide to the Coastal Environments of 551 Northern Ireland 
553 Navas, F. \& Cooper, J.A.G. 1998. Interactions between long term coastal

554 change and human development, Dundrum Bay, Northern Ireland. Journal of

555 Coastal Research Special Issue 26 (2), 71-77.

557 Navas, F., Malvarez, G.C., Jackson, D.W.T., Cooper, J.A.G. \& Portig, A.A.

558 2002. Geomorphological and biological monitoring of sensitive intertidal

559 flat environments. Journal of Coastal Research, Special Issue 36, 531-543.

560

561 Odum, W. 1982. Environmental Degradation and the Tyranny of Small

562 Decisions. BioScience, 32, 728-729.

563

564 Orford, J.D., Betts, N., Cooper, J.A.G. and Smith, B.J. 2006. Future Coastal 565 Scenarios for Northern Ireland. Unpublished Report to National Trust.

567 Orr, D. 2010. The Antrim Coast Road - a civil engineering legacy.

568 Proceedings - Engineering History and Heritage - Issue EH2 (London:

569 Institution of Civil Engineers): 68.

571 Penning-Rowsell, E. C., Priest, S.J., Parker, D.J., Morris, J. Tunstall, S.M.,

572 Viviattene, C., Chatterton, J. and Owen, D. 2013. Flood and coastal erosion 
573 risk management: a manual for economic appraisal. Routledge, Taylor \& 574 Francis, London, UK.

575

576 Rayner,

D.

(2006)

Coastal

Management.

577 http://www.georesources.co.uk/coastman.htm Last accessed 26/01/11

579 UK National Ecosystem Assessment (2011) The UK National Ecosystem 580 Assessment Technical Report. UNEP-WCMC, Cambridge.

581 Van Koningsveld, M. Mulder, J. P. M. Stive, M. J. F. VanDerValk, L. and 582 VanDerWeck A. W. (2008) Living with Sea-Level Rise and Climate 583 Change: A Case Study of the Netherlands. Journal of Coastal Research, 24, $584367-379$.

588 Figure Captions

590 Figure 1. Map of Northern Ireland showing main roads, coastal towns Areas 591 of Outstanding Natural Beauty (AONB's) 
593 Figure 2. Map of North coast from Magilligan to Ballycastle illustrating the 594 location of Lough Foyle and including major towns, roads and AONB.

596 Figure 3. Sea defences on the north coast. A. Curved seawall and 597 promenade, West Strand, Portrush. B. Seawall and promenade at East 598 Strand, Portrush. This suffers regular inundation with wind-blown sand and 599 requires regular mechanical clearing. C. Rock armour to protect part of gold 600 course. D. Portballintrae groynes, seawall and stabilized back-beach slope. 601

602 Figure 4. Map of the North Antrim coast from Ballycastle to Larne 603 illustrating Larne Lough.

604

605 Figure 5. A. Cushendun rock armouring at a car park. B. Railway sleepers 606 used as sea defence, Cushendun. C. Sloping stone wall, Cushendall. 607 Gabbion baskets, Red Bay. E. and F. Near vertical, stepped seawall at 608 Carnlough at low and high tide.

610 Figure 6. Map of the Outer Ards coast from Larne Lough to Dundrum Bay. 
612 Figure 7. Sea defences on the outer Ards Peninsula. A. wall and rock

613 armour defending house. B. concrete wall defending car park. C. Concrete

614 wall defending road. D. Rubble dumped as sea defence. E. Vertical wall

615 defending road. F. Massive rock armour defending road.

617 Figure 8. Ballyholme, Bangor. A. Sea wall and subsequent toe defence. B. 618 Low promenade and seawall. C/ Groynefield/ D. Collapsing concrete 619 groynes

620

621 Figure 9 Map of the South Down coast from Newtownards to Warrenpoint 622 including Strangford Lough, Dundrum Bay and Carlingford Lough.

624 Figure 10. A. Rock armour fronting Newcastle promenade. B. Failed sea 625 defence, Slieve Donard Hotel, 2002. C. Gabbion armouring of coastal 626 footpath, Annalong. D. Rock armour of agricultural land.

628 Figure 11. Sea defences on estuarine beaches. A. Crawfordsburn, Belfast 629 Lough. Seawall and promenade. B. Rock armour protecting picnic site, 630 Strangford Lough, Sea Defences protecting Newtownards from flooding,. 631 D. Vertical wall with several generations of repairs, protecting road, 
632 Strangford Lough. E. Rock armour protecting beachfront house, Carlingford

633 Lough. F. Rock armour defences fronting new development, Carlingford

\section{Lough}

635

636

637

638

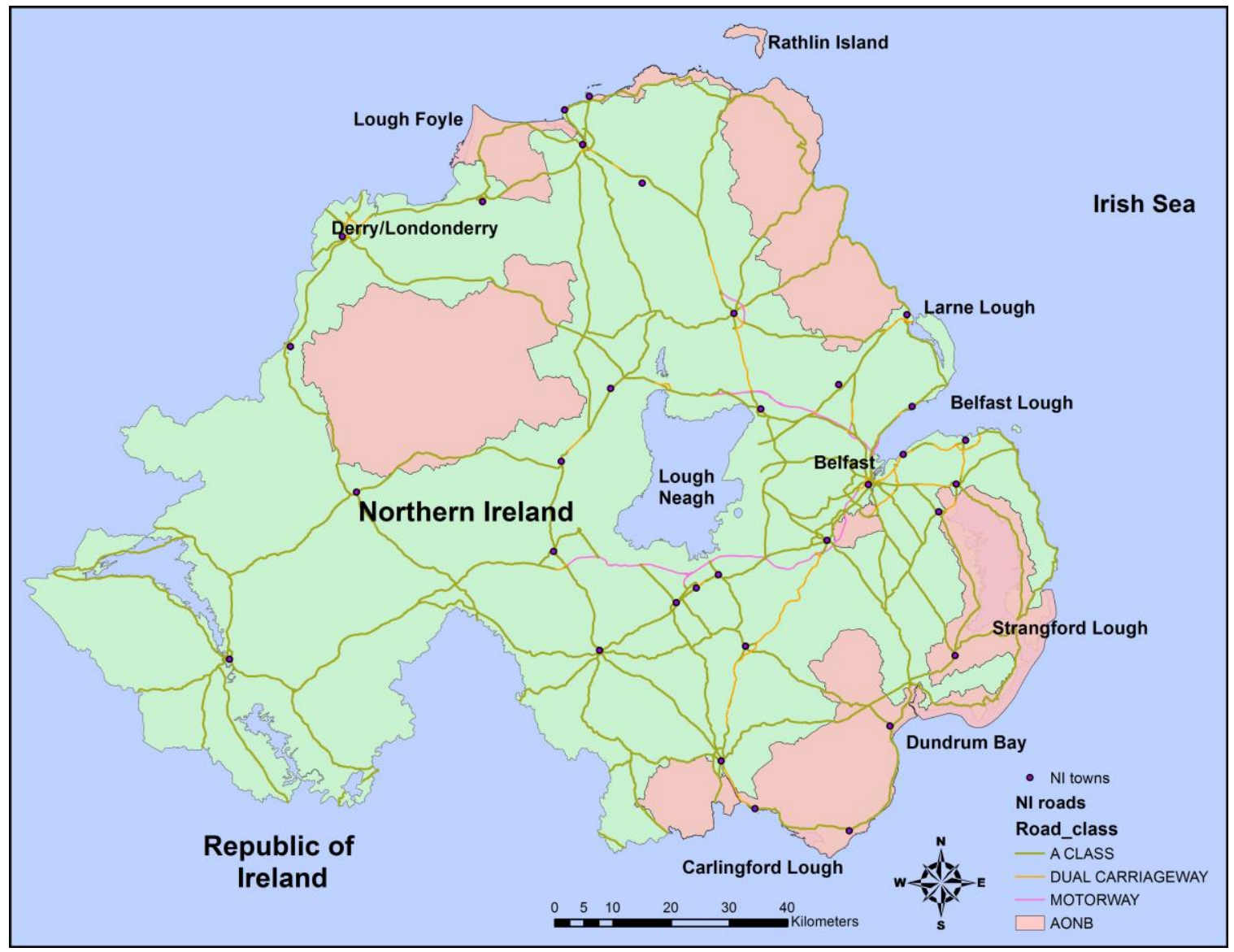

640 Figure 1. Map of Northern Ireland showing main roads, coastal towns Areas of 641 Outstanding Natural Beauty (AONB's) 


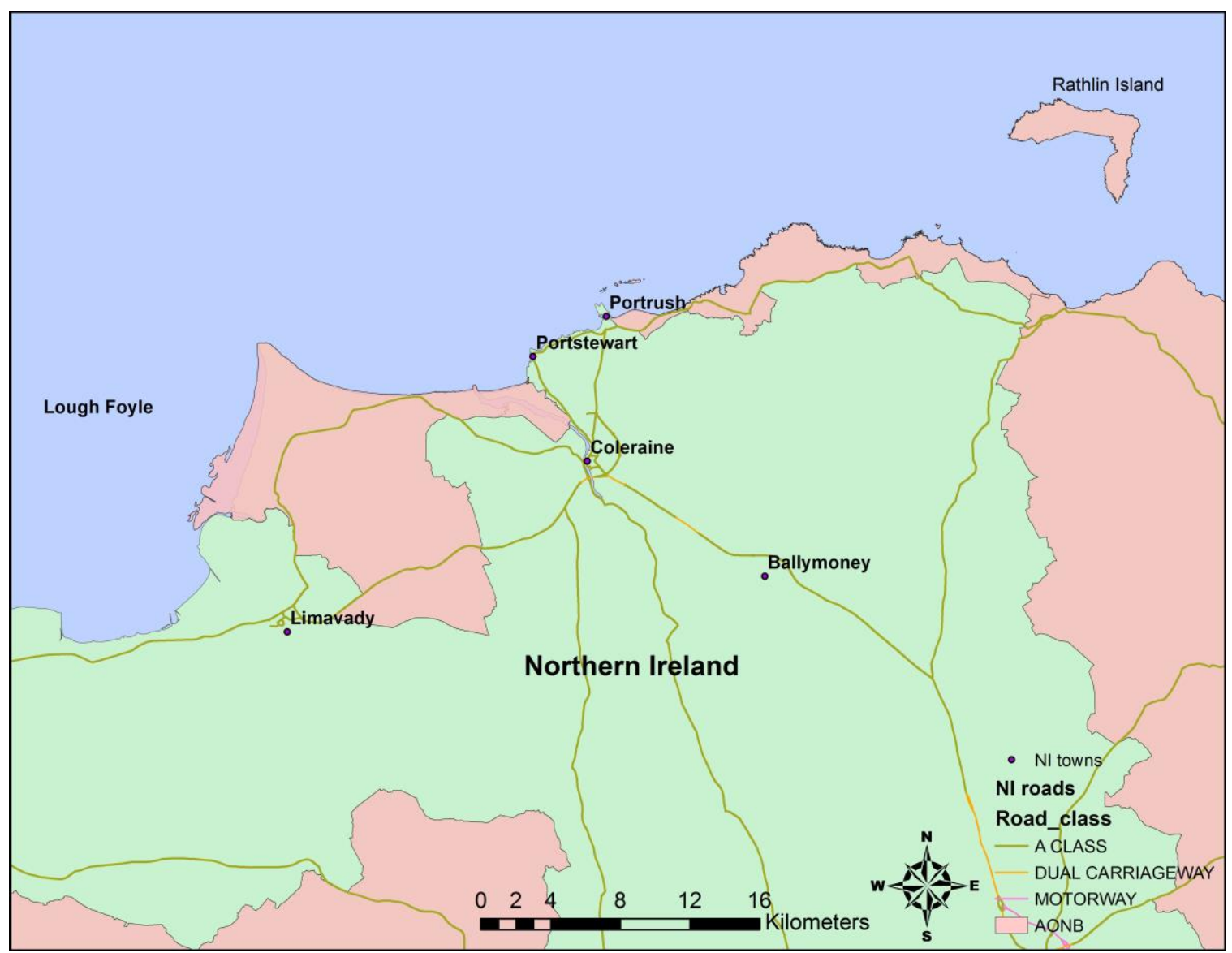

Figure 2. Map of North coast from Magilligan to Ballycastle illustrating the location of

646 


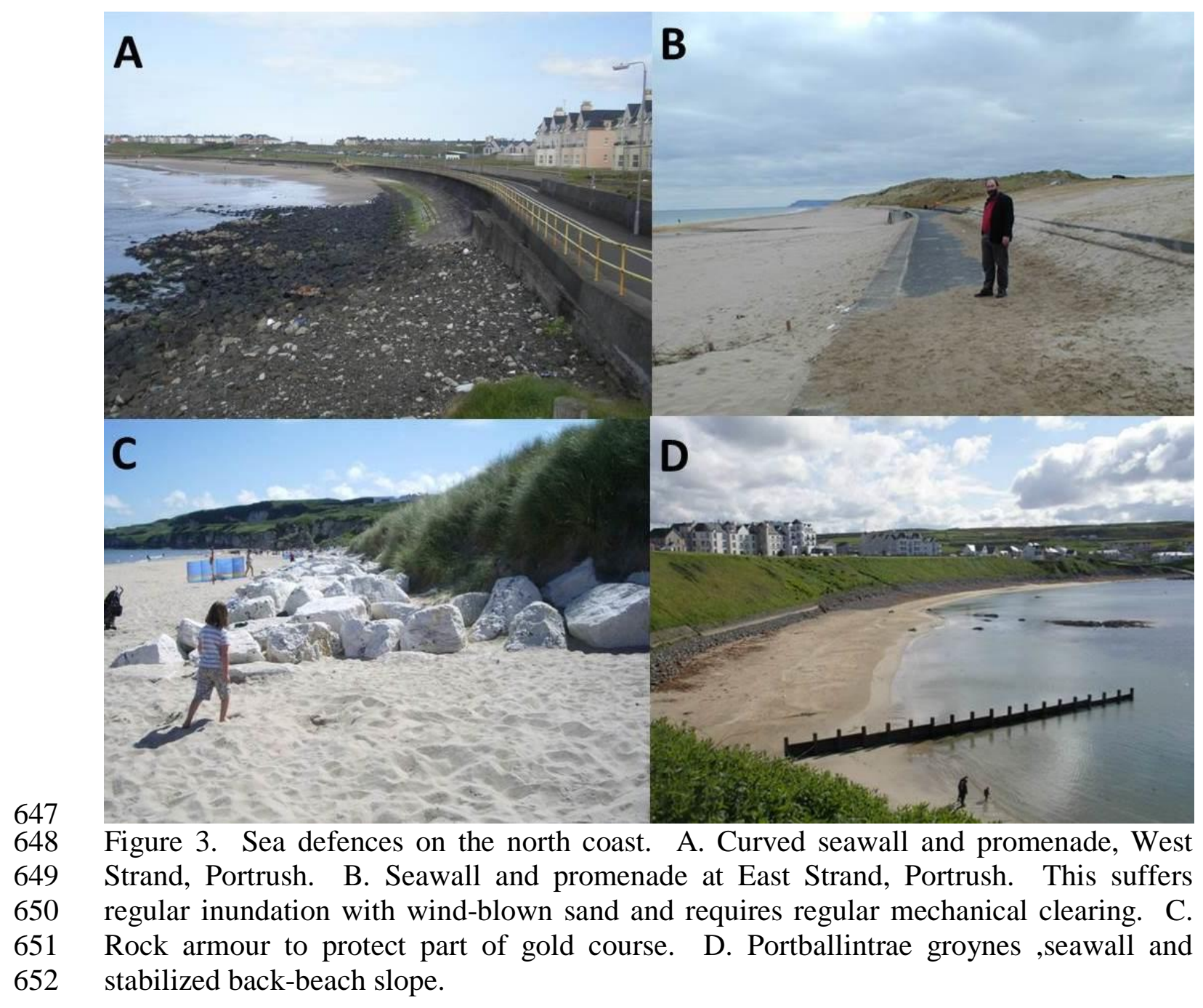


654 Figure 4. Map of the North Antrim coast from Ballycastle to Larne illustrating Larne 655 Lough. 

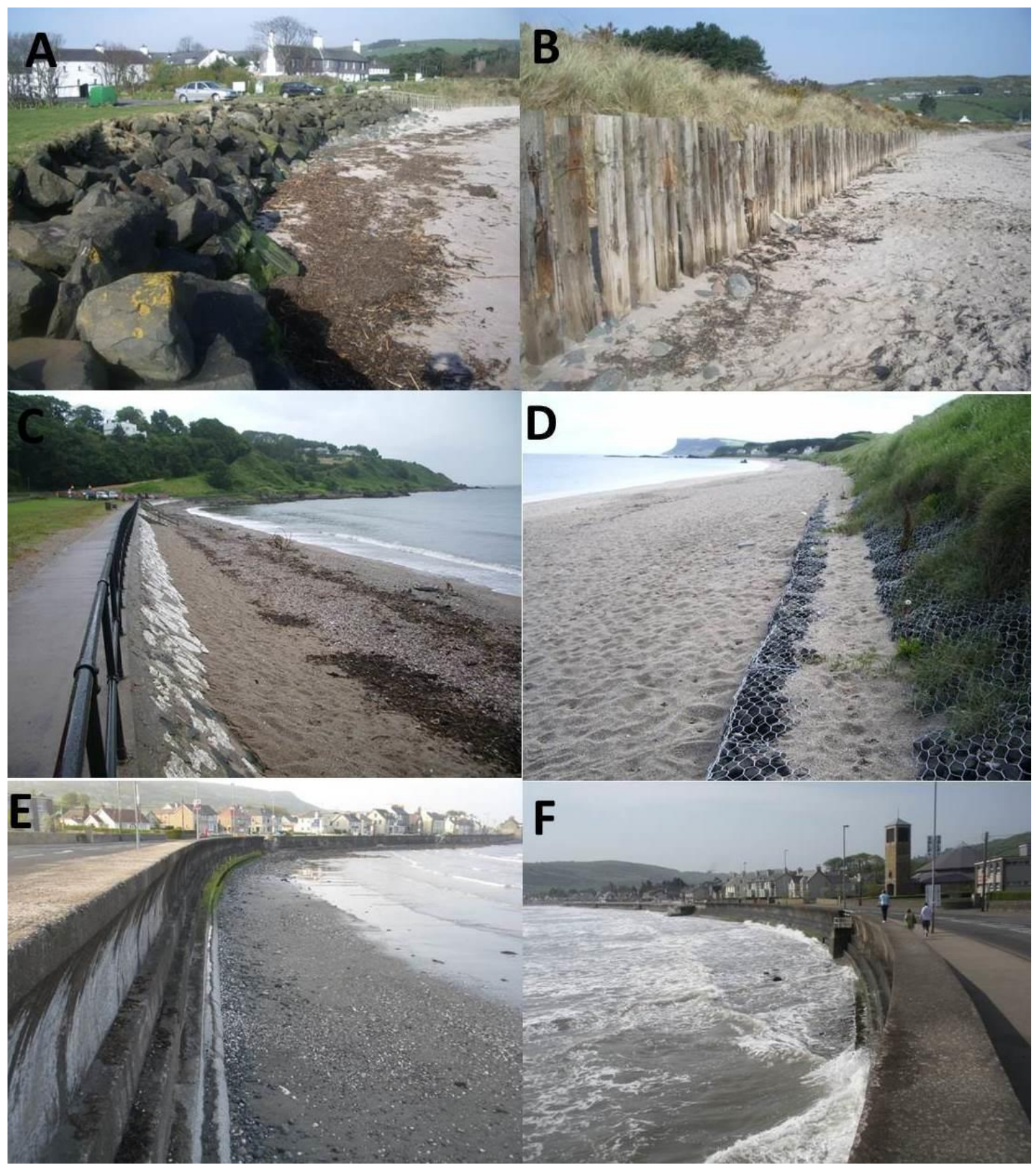

658 Figure 5. A. Cushendun rock armouring at a car park. B. Railway sleepers used as sea 659 defence, Cushendun. C. Sloping stone wall, Cushendall. Gabbion baskets, Red Bay. E. 660 and F. Near vertical, stepped seawall at Carnlough at low and high tide. 


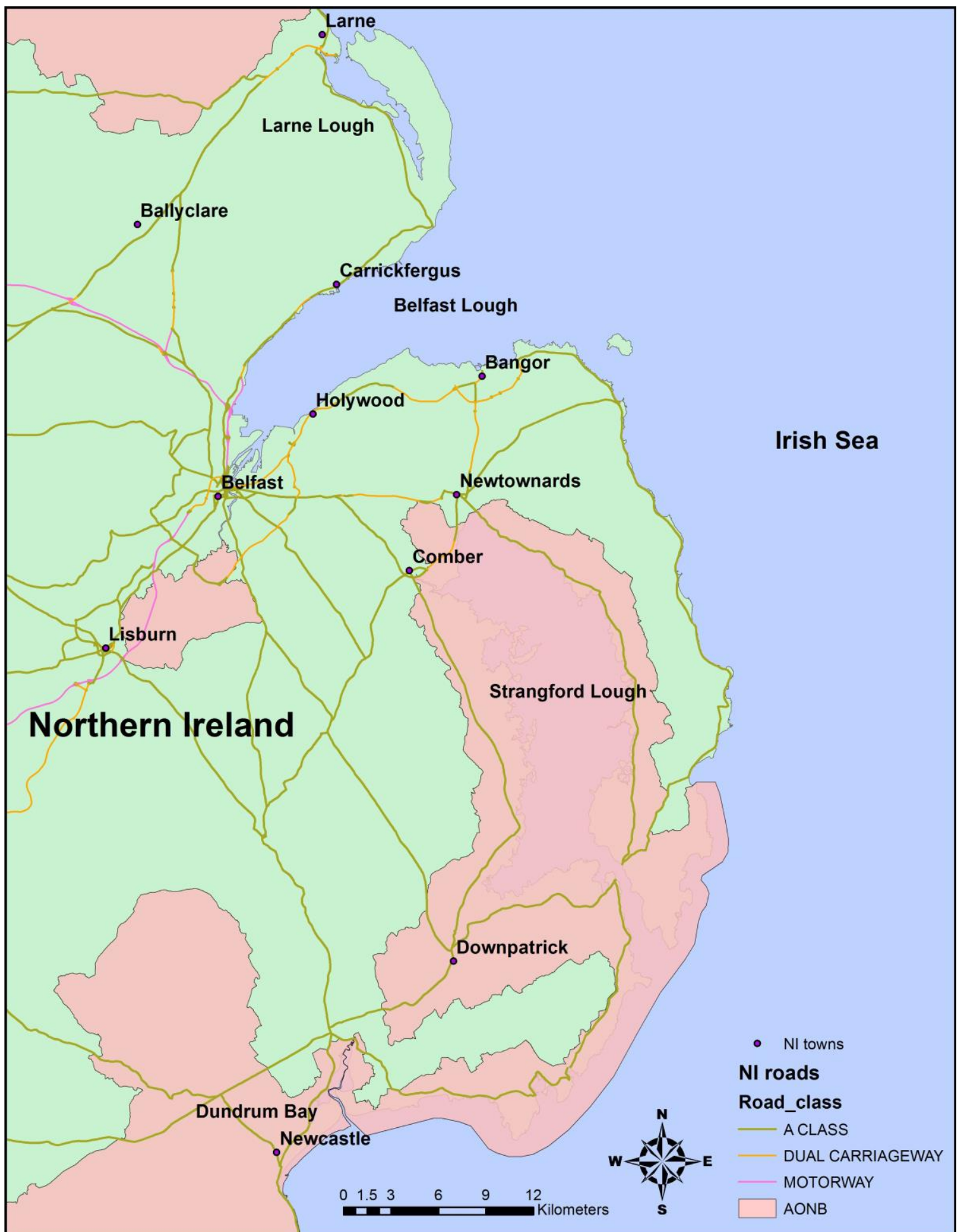

661

Figure 6. Map of the Outer Ards coast from Larne Lough to Dundrum Bay. 


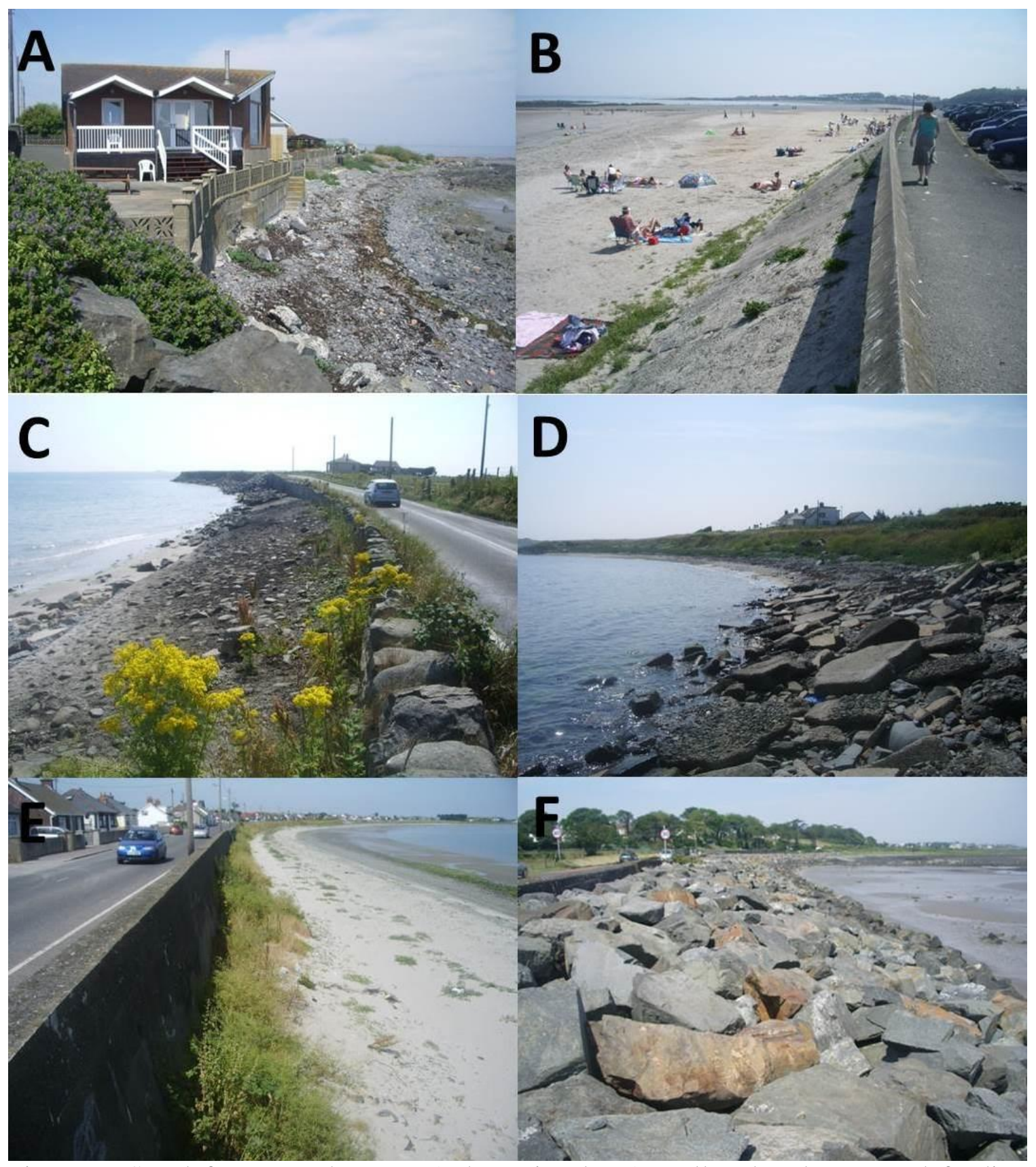

667 house. B. concrete wall defending car park. C. Concrete wall defending road. D. 668 Rubble dumped as sea defence. E. Vertical wall defending road. F. Massive rock armour 669 defending road. 

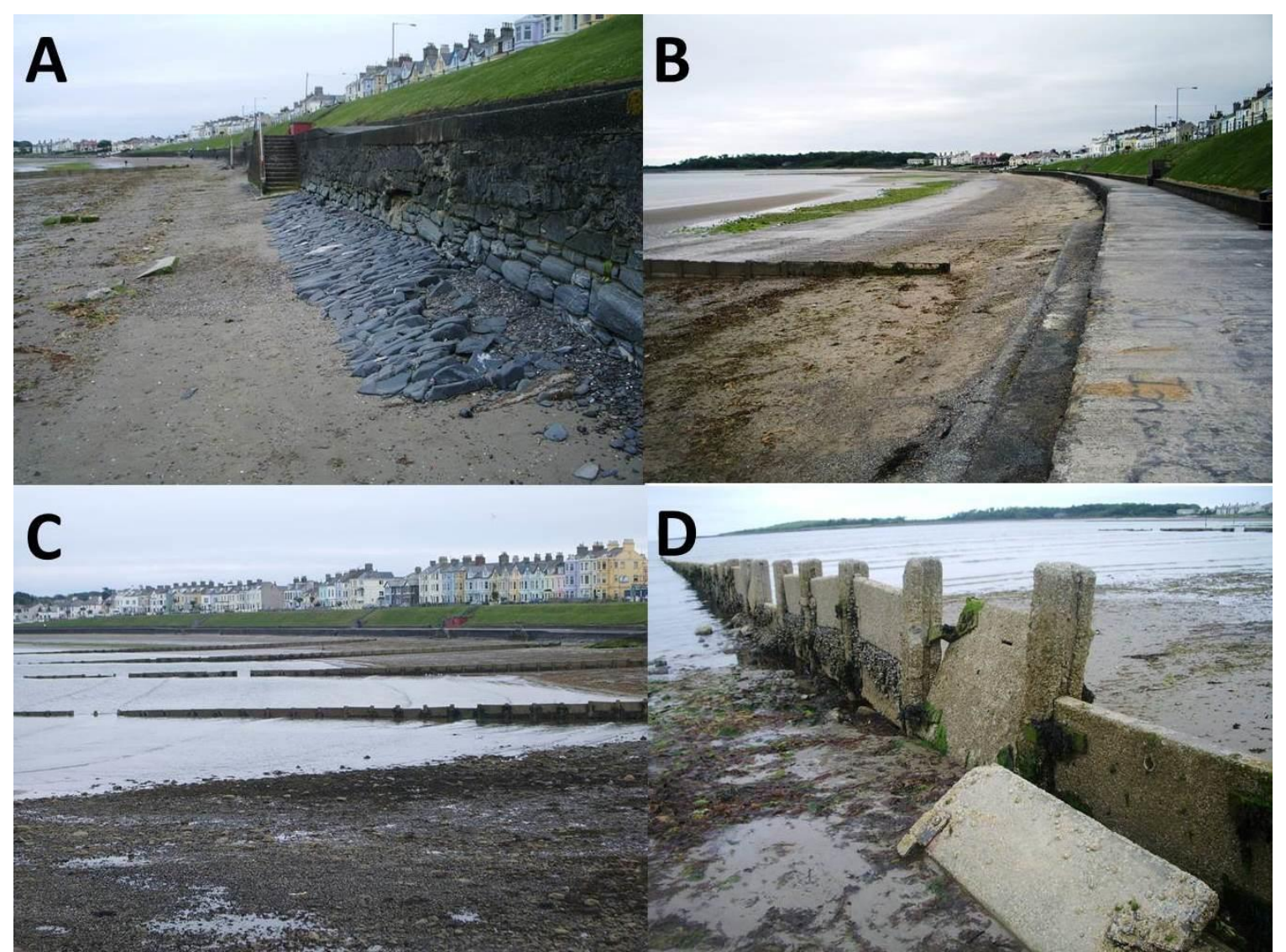

675 Figure 8. Ballyholme, Bangor. A. Sea wall and subsequent toe defence. B. Low 676 promenade and seawall. C/ Groynefield/ D. Collapsing concrete groynes 


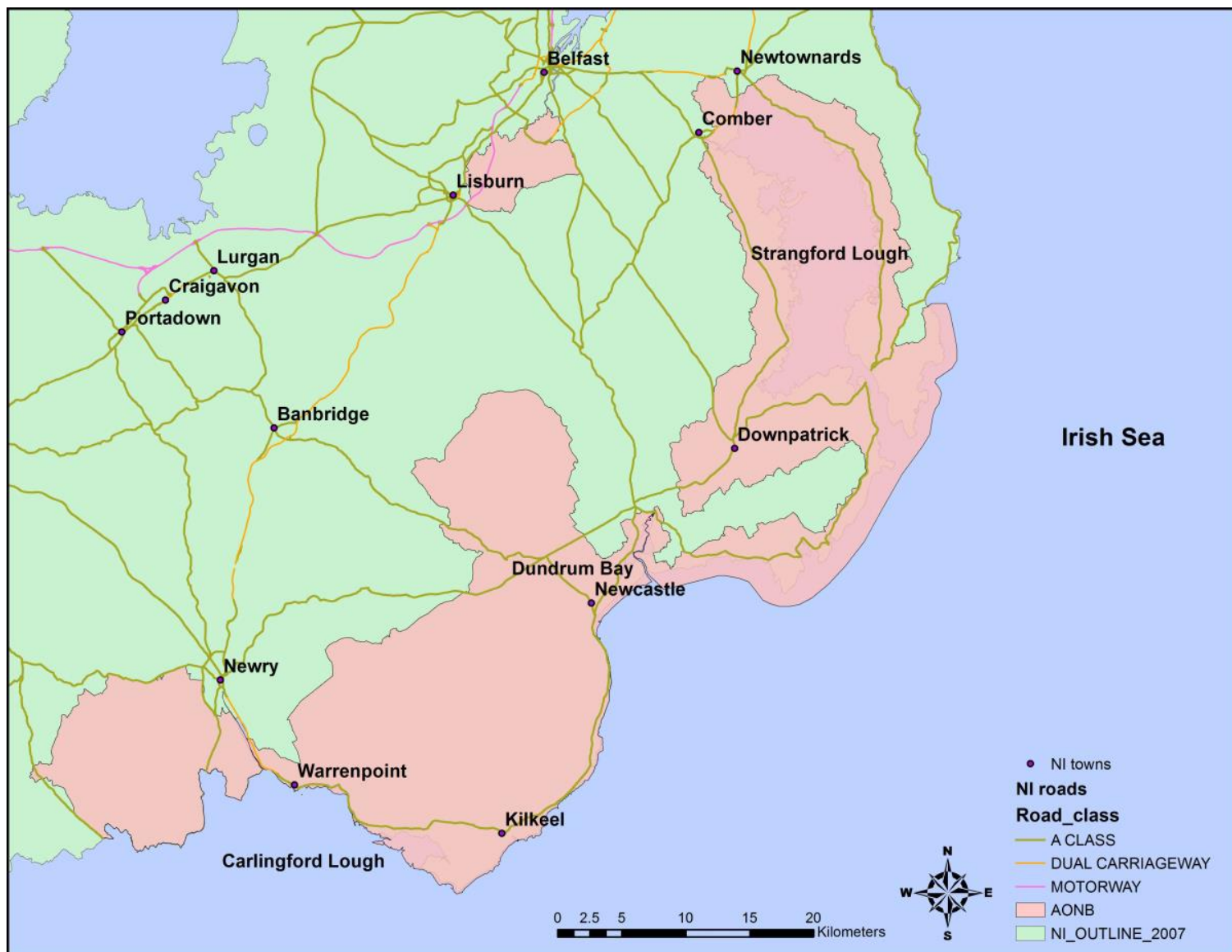

680

681

682

683 

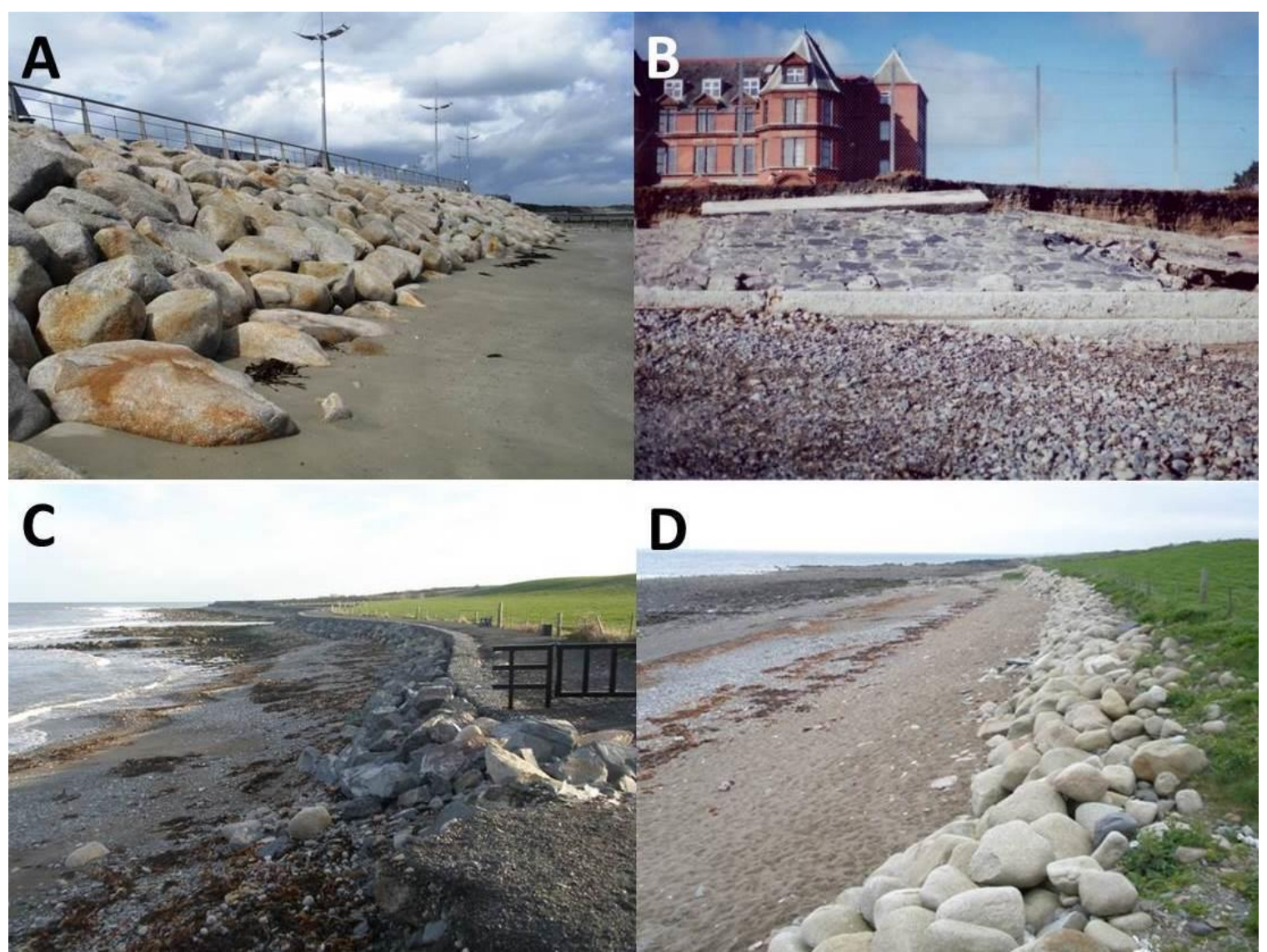

Figure 10. A. Rock armour fronting Newcastle promenade. B. Failed sea defence, Slieve 686 Donard Hotel, 2002. C. Gabbion armouring of coastal footpath, Annalong. D. Rock 687 armour of agricultural land. 


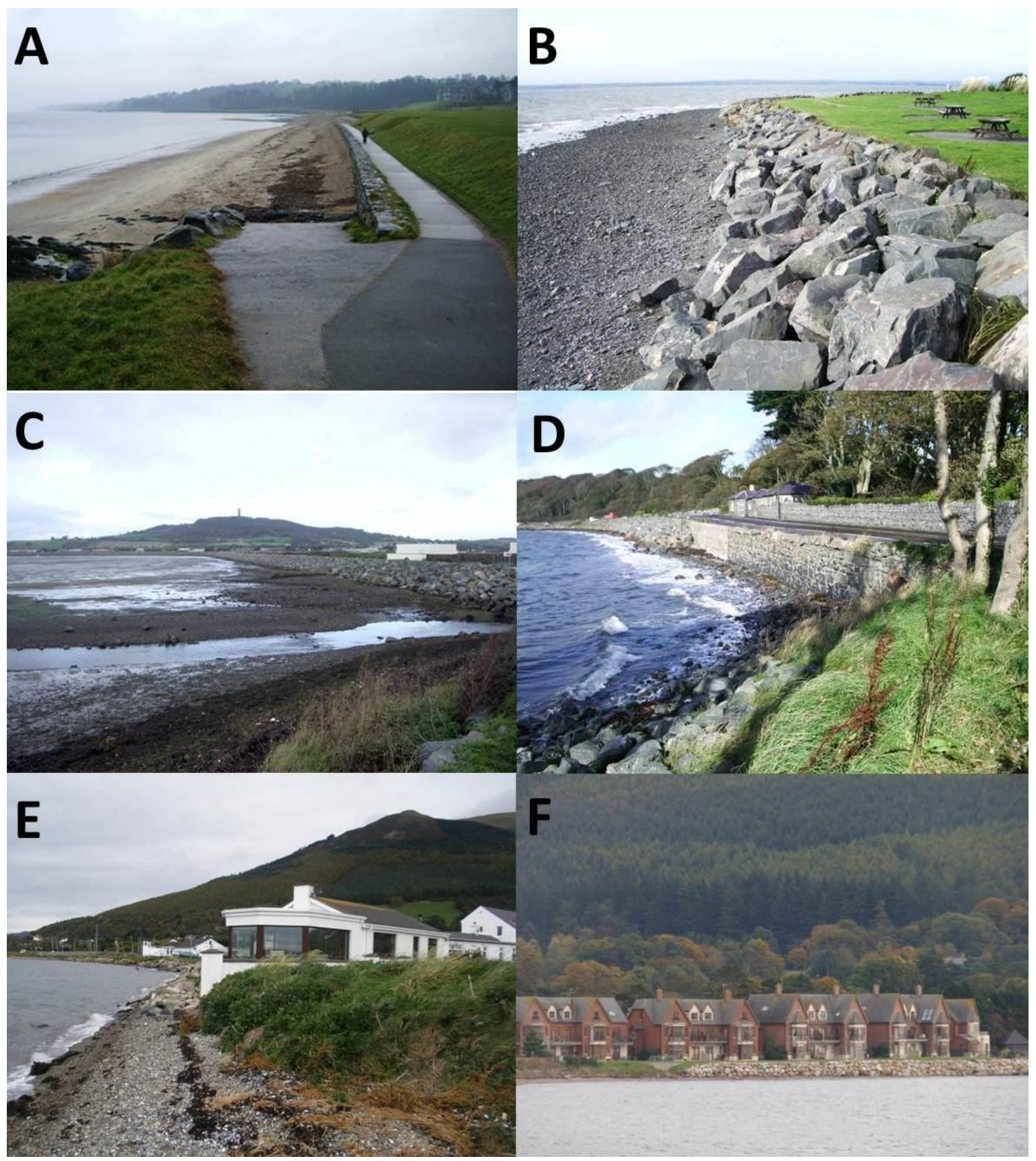

Figure 11. Sea defences on estuarine beaches. A. Crawfordsburn, Belfast Lough. Seawall

691 and promenade. B. Rock armour protecting picnic site, Strangford Lough, Sea Defences

692 protecting Newtownards from flooding,. D. Vertical wall with several generations of 693 repairs, protecting road, Strangford Lough. E. Rock armour protecting beachfront house,

694 Carlingford Lough. F. Rock armour defences fronting new development, Carlingford 695 Lough 